\title{
Investigating the Plagiarism Awareness among Malaysian undergraduates in Summative Assessment
}

\author{
Najihah Mahmud ${ }^{1}$, Nazirah Mahmud ${ }^{2}$, Ariezal Afzan Hassan ${ }^{3}$, \& Nor Hazwani Munirah \\ Lateh $^{4}$ \\ \{najihah.m@umk.edu.my ${ }^{1}$, nazeerah@usas.edu.my ${ }^{2}$, ariezal@umk.edu.my ${ }^{3}$, \\ hazwani.1@umk.edu.my $\left.{ }^{4}\right\}$
}

Universiti Malaysia Kelantan, 16300 Bachok Kelantan, Malaysia ${ }^{1,3,4}$, Universiti Sultan Azlan Shah, 33000 Kuala Kangsar Perak, Malaysia ${ }^{2}$

\begin{abstract}
This preliminary study explored the level of plagiarism awareness among Malaysian undergraduates when carrying out their summative assessment. In the field of language assessment, summative assessment in the form of graded task is regarded as an effective tool to exercise change as it could highly influence the teaching and learning. However, concern regarding students' plagiarism behaviour is increasing despite the exposure given to them by their respective instructors. Therefore, this study aimed to fill this gap by investigating if there was any relationship between the students' perceived plagiarism awareness with their Turnitin similarity index score of their summative assessments. The graded task under investigation was in the form of argumentative essay. Using a quantitative approach, student questionnaire and document analysis were utilised to elicit data from 30 undergraduates. It was found that although the students appeared to be aware of plagiarism, their practices in their summative assessment indicated otherwise.
\end{abstract}

Keywords: plagiarism, awareness, Turnitin, summative assessment, writing

\section{Introduction}

In tertiary education, plagiarism is, without doubt, an unavoidable issue both among the lecturers and the students. It is even more severe when it comes to graded assessment especially course assignments. This could be attributed to the easy accessibility of vast amount of information and resources both online and offline. In this study, plagiarism is defined as "the action or practice of taking someone else's work, ideas, etc., and passing it off as one's own; ie literary theft" [1]. According to an author [2] 15 years ago, there was a steady increase of academic dishonesty and plagiarism in universities around the world and in 2020, this issue is progressing at an alarming rate.

Due to the advancement of technology and Industrial Revolution 4.0, more and more technology has been injected into the teaching and learning system, making it easy for learners to transfer information from the world wide web into their graded assignments without properly citing the work. Some were aware of their plagiarism behaviour whilst some appeared to be rather ignorant about it. In a study on awareness about plagiarism amongst university students in Pakistan [3], it was reported that quite a large number of university students simply did not know what plagiarism actually mean. Even if they did know the definition of plagiarism, they 


\section{Kresna Social Science and Humanities Research}

Proceedings of the International Conference On Ummah:

Digital Innovation, Humanities And Economy (ICU: DIHEc) 2020

https://doi.10.30874/ksshr.41

did not consider plagiarism as wrong, indicating that they were aware of it but they did not understand what plagiarism is about. This could be the case in the context of the present study, Malaysia. It was observed that the practice of copy and paste information from other sources, be it online or offline, without proper citation, into their work and submitted it as their graded assessment is quite common.

As reported in the literature on plagiarism, various explanations or perhaps 'excuses' were given to justify their plagiarism behaviour, with internet and technology being commonly blamed as the culprit [4]. Other than that, students' unwillingness to learn was also attributed to plagiarism [5]. These different contrastive opinions not only create more confusion on this issue but to this date, the problem related to plagiarism remain unsolved. Students appeared to be aware of the concept pertaining to plagiarism but to what extent do they actually understand it is still rather poorly explored. An author [6] explained that sometimes, it was not entirely the students' fault when it comes to plagiarism because it could be that the students themselves were not aware that they were actually plagiarising when referring to others' work with no proper credit given.

Hence, this present study aimed at exploring the students' perceived awareness level of plagiarism and its relation to their actual plagiarism behaviour when carrying out their summative assessment.

\section{Methodology}

Quantitative approach was used in this preliminary study by adopting the Plagiarism Awareness Questionnaire developed by few researchers [2] in their empirical study in Pakistan. A number of 30 students undertaking Advanced Grammar for Undergraduates at Universiti Malaysia Kelantan were chosen to participate in this study. Aside from the questionnaire, the students' Turnitin similarity index scores for their Argumentative Essay assignment were recorded as well in order to see the relationship between their perceived level of plagiarism awareness with their actual writing convention in relation to plagiarism. This is crucial in order to see if their perceived plagiarism awareness correlate with their Turnitin score.

\section{Discussion of Findings}

Out of 30 respondents from the preliminary study, 21 students scored $0 \%$ Turnitin similarity index for their essays. From the cross-section tabulation between gender and students' Turnitin score, it was found that all male respondents $(n=8)$ scored $0 \%$ as opposed to the female $(n=22)$, with $58 \%$ similarity index being the highest. It was also reported that the students with high proficiency in English language were not necessarily free of plagiarism. 


\section{Kresna Social Science and Humanities Research}

Proceedings of the International Conference On Ummah:

Digital Innovation, Humanities And Economy (ICU: DIHEc) 2020

https://doi.10.30874/ksshr.41

Table 1. Students' awareness of plagiarism

\begin{tabular}{|c|c|c|c|c|c|c|}
\hline No. & Example & $\begin{array}{l}\text { Strongly } \\
\text { Disagree }\end{array}$ & Disagree & Agree & $\begin{array}{l}\text { Strongly } \\
\text { Agree }\end{array}$ & Mean \\
\hline A1 & I understand the meaning of plagiarism & 0 & 0 & 53.3 & 46.7 & 3.47 \\
\hline A2 & I understand plagiarism to be wrong & 0 & 6.7 & 56.7 & 36.7 & 3.30 \\
\hline A3 & $\begin{array}{l}\text { Copying from a book without crediting } \\
\text { the source constitutes plagiarism }\end{array}$ & 3.3 & 3.3 & 40.0 & 53.3 & 3.43 \\
\hline A4 & $\begin{array}{l}\text { If a student violates the plagiarism policy } \\
\text { he/she will be caught }\end{array}$ & 0 & 10.0 & 56.7 & 33.3 & 3.23 \\
\hline A5 & $\begin{array}{l}\text { If a student violates the plagiarism policy } \\
\text { he/she will be caught and face serious } \\
\text { consequences }\end{array}$ & 0 & 13.3 & 56.7 & 30.0 & 3.17 \\
\hline A6 & $\begin{array}{l}\text { Our faculty is effective at catching } \\
\text { students who plagiarize }\end{array}$ & 3.3 & 16.7 & 60.0 & 20.0 & 2.97 \\
\hline A7 & $\begin{array}{l}\text { University is effective at catching } \\
\text { students who plagiarize }\end{array}$ & 0 & 10.0 & 63.3 & 26.7 & 3.17 \\
\hline
\end{tabular}

Seven items on plagiarism awareness were utilised to examine undergraduates' level of awareness in relation to plagiarism. The preliminary findings revealed that majority of the students understood the meaning of plagiarism but two of them did not think that plagiarism is wrong. Even though the number is low, it is interesting to note that the students disagree copying from a book without crediting the source constitutes as plagiarism. In academia, this can be considered as a very serious misconduct and students especially those who are at the tertiary level of education are expected to at least be aware of this practice.

As depicted in Table 1, some of the students disagree that if they violated the plagiarism policy, they will be caught and face serious consequences. This could be attributed to the findings for items A6, and A7, where both their faculty and university were deemed inefficient at catching students who plagiarize. Hence, they were of the opinion that it was okay for them to do it because there would be no serious repercussion of not citing others' works properly.

A crosstabulation between students' plagiarism awareness level and their Turnitin score was run and it was found that even if their awareness level on plagiarism was high $($ Mean $=$ 3.43 ), they would still plagiarise in their written work (Turnitin similarity index $=58 \%$ ). It was safe to assume that they either understood the concept of plagiarism wrongly, or they thought that they would not be caught for committing an academic crime of plagiarism. They did not seem to register the seriousness of this issue and this could be because their level of awareness might not be as high as the postgraduate students who are more exposed to this.

\section{Conclusion}

From this study, it can be seen that in general, the level of the students' plagiarism awareness is quite high and most of them did not plagiarize when carrying out their written 


\section{Kresna Social Science and Humanities Research}

Proceedings of the International Conference On Ummah:

Digital Innovation, Humanities And Economy (ICU: DIHEc) 2020

https://doi.10.30874/ksshr.41

assignment. However, there were still a number of students who did not seem to fully grasp the concept of plagiarism and more exposure were deemed necessary at this rate in order to ensure that this problem could somehow be reduced. There needs to be a clear policy especially at the faculty level pertaining to plagiarism and the consequences that the students will face if they commit the 'academic crime' in order to instil a sense of responsibility not only to their own written work, but also when citing others'.

Since this was a preliminary study, the scope was rather limited. Further research should look more into the writing strategies that students utilised when doing their written assignment in order to understand the justification behind their plagiarism behaviour further.

Acknowledgements This work was supported by a research grant provided by Universiti Malaysia Kelantan (R/SGJP/A0400/01060A/ 001/2019/00596).

\section{References}

[1] Oxford English Dictionary. Plagiarism. http://www.oed.com/view/Entry/144939. 2019.

[2] Brimble, M., Stevenson-Clarke, P. Perceptions of the prevalence and seriousness of academic dishonesty in Australian universities. AER. 2005; 32(3):19-44.

[3] Ramzan M, Munir MA, Siddique N, Asif M. Awareness about plagiarism amongst university students in Pakistan. Higher education. 2012 Jul 1;64(1):73-84.

[4] Comas-Forgas R, Sureda-Negre J. Academic plagiarism: Explanatory factors from students' perspective. Journal of Academic Ethics. 2010 Sep 1;8(3):217-32.

[5] Malesic J. How Dumb Do They Think We Are?. Chronicle of Higher Education. 2006 Dec 15;53(9).

[6] Zejno B. Plagiarism in academic writing among students of higher learning Institutions in Malaysia: An Islamic perspective. Journal of Education and Social Sciences. 2018;9(3):1-4. 